\title{
The Effect of Brand Experience, Brand Personality and Brand Trust on Brand Loyalty
}

\author{
Howardi Visza Adha ${ }^{*}$, \\ Wiry Utami ${ }^{2}$, \\ 1 Department of Entrepreneur, Faculty of Economics, Universitas Baiturrahmah, Padang, \\ Indonesia \\ 2 Department of Management, Faculty of Economics and Business, Universitas Bung Hatta, Padang, \\ Indonesia
}

\begin{tabular}{ll}
\hline ARTICLE INFO & ABSTRACT \\
\hline ISSN: 2723-1097 & $\begin{array}{l}\text { This study conducted to determine the effect of brand experience, brand personality } \\
\text { and brand trust on brand loyalty. This study is an explanatory research. The } \\
\text { method used in this study is a quantitative method using survey methods. The total } \\
\text { sample in this study was 150 respondents with the technique of taking with the }\end{array}$ \\
Keywords: & $\begin{array}{l}\text { method of purposive sampling. Primary data in this research is obtained from } \\
\text { questionnaires distributed to respondents, while secondary data is data related to }\end{array}$ \\
Brand Experience, & the object of research presented by other parties. Data analysis techniques in this \\
Brand Trust, Brand & study using simple regression analysis. The result of the research shows that: (1) \\
Loyalty & brand experience has positive effect on brand loyalty, (2) brand personality has \\
positive effect on brand loyalty, (3) Brand trust has positive effect on brand loyalty.
\end{tabular}

\section{Introduction}

The shopping style of the Indonesian society is starting to change. Now, the Indonesian society prefers to transact online rather than conventionally (money.kompas.com). This is due to the various conveniences of shopping online, one of which is through online shopping we can see the items to be purchased first. With this online shopping activity, we do not need to meet face to face directly, but can be done separately from and to the rest of the world via electronic media such as notebooks, computers and smartphones connected to internet access services. Online shopping can be carried out through a platform where sellers gather and can sell goods or services to consumers even though they do not meet physically, this is what is called a marketplace. In Indonesia, the marketplace is one of the platforms that are often used for trading. The competition in the marketplace is very tight, old players and new players in the marketplace companies must compete to get consumers (money.kompas.com). This makes it difficult for them to retain consumers. In order to compete, marketplace companies are led to develop their business and link with brands so that they can add value to their business.

Journal of Business and Management Review Vol. 2 No. 122021 Page 861-871

DOI: $10.47153 /$ jbmr212.2962021

*Corresponding Author

Email address: howardivisza@fekon.unbrah.ac.id 
A brand is a name, term, sign, symbol, or design, or a combination of both, intended to identify the goods or services of one seller or group of sellers and to differentiate them from those of competitors (Kotler \& Keller, 2016). With the number of marketplaces that can be accessed by consumers, brands are expected to provide uniqueness as an added value to differentiate them from other marketplace brands. In Indonesia, there are several marketplaces that compete to get consumers' attention, such as Shopee.co.id, Lazada.co.id, Tokopedia.com, Bukalapak.com, Blibli.com, etc. They use the marketplace to online shopping. Online shopping is the process of purchasing products and services using the internet. They can browse the items just by looking at the website and they can directly make online purchase (Utami et al., 2021). In the marketplace competition in Indonesia, Lazada.co.id leads the market in 2019-2021, this is in accordance with data from topbrand-award.com that Lazada.co.id leads with TBI in 2019 of $31.6 \%$ and $31.9 \%$ in 2017 . However, there will be a drastic decline in 2021 with a TBI of $15.2 \%$ and a free fall from first place to third place. From this data, it can be seen that there was a drastic decline experienced by Lazada.co.id, this is related to the decrease in consumers using the Lazada.co.id marketplace. For this reason, researchers are interested in researching brand loyalty in the Lazada.co.id marketplace.

Brand loyalty is a behave in buying that expressed from time to time by several decision-making units that indicate conditions of a certain time duration and require that the purchase action occur no less than twice. In other words, brand loyalty is an attitude of consumers who honestly feel satisfaction from the results of purchasing products or services provided by producers or sellers, so that consumers will repeatedly buy the products needed so that a long-term relationship will be created. According to Mowen \& Minor, (2002) suggest the notion of brand loyalty as a condition in which consumers have a positive attitude towards a brand, are committed to the brand and intend to continue purchasing in the future.

To be more attractive to consumers, apart from having a positive attitude, marketplace companies must also be able to approach brand experience. While Nysveen et al., (2013) suggested brand experience as a function of a set of interactions between consumers and organizations, stimulated by direct interaction (with a product) or indirect contact (communication) with the company, personally and easily remembered. In recent decades, several studies have suggested that brands provide experiences to consumers Beckman et al., (2013); Brakus et al., (2009);Dennis et al., (2014); Ding \& Tseng ", (2015); Nysveen et al., (2013). Brand experience is conceptualized as sensory, effective, cognitive, behavioural, and social responses to brand-related stimulation from brand marketing activities (Brakus et al., 2009). Thus, brand experience refers to consumers' perceptions of their experiences with brands (Ding \& Tseng, 2015). Brands that already have loyalty and experience can form a personality called the brand personality of their consumers. With the company's 
efforts to project a certain brand image through advertising and communication, brand attributes, and the results of consumer associations, a brand personality will emerge. Brands that are close to the consumer's personality will be chosen by consumers. Based on the research results, the findings of several experts suggest that humans and brand personality support each other (Lin, 2010).

According to Japutra \& Molinillo (2019) brand personality is defined as human personality traits and characteristics. A superior brand personality and in accordance with the customer's personality is formed from a good bond between the consumer and the brand. Apart from brand personality, brand trust and brand loyalty are also important for brand experience (Brakus et al., 2009). Brand experience can positively affect consumer satisfaction and brand loyalty, as well as brand trust (Zarantonello \& Schmitt, 2010). For this reason, there is a very close relationship between brand experience and brand trust.

Brand trust is defined as the willingness of consumers to rely on the brand in the face of the risk of expectations or expectations that the brand will have positive results in addition to brand trust will also have implications for brand loyalty. Based on the description, researchers are interested in knowing the effect of brand experience, brand personality, brand trust on brand loyalty on the Lazada.co.id marketplace.

\section{Literature Review}

\section{Brand Loyalty}

Brand loyalty is a held commitment to either repurchase or subscribe to a particular product or service in the future despite situational influences and marketing efforts that have the potential to cause behavioural switching (Oliver, 1999). Brand loyalty shows a condition of certain duration of time and requires that the purchase action occurs no less than twice. Meanwhile, Mowen \& Minor, (2002) suggest the notion of brand loyalty is a condition where consumers have a positive attitude towards a brand, have a commitment to the brand and intend to continue buying in the future. So it can be concluded that brand loyalty is a positive attitude of consumers towards a product or brand which is obtained from learning outcomes and is realized by making repeat purchases on a regular basis, so that a long-term relationship will be created.

\section{Brand Experience}

Customer experience as a function of a set of interactions between a customer and an organization, stimulated either through direct interactions (product) or indirect contact (communication) with company, in a personal and memorable way (Nysveen 
et al., 2013). In the last decade, an emergent research stream suggests. Brand Experience is conceptualized as consumer's sensory, affective, cognitive, behavioural, and social responses to the brand-related stimuli from the brand marketing activities (Brakus et al., 2009). Thus, Brand Experience refers to the consumer's perception of their experience with the brand (Ding \& Tseng, 2015).

According to (Brakus et al., 2009) brand experience include four dimensions of experiences: sensory, affective, intellectual, and behavioural. Sensory experiences refer to the sensations to the consumer five senses (touch), affective experiences refer to a wide range of feelings (fun), intellectual experiences refer to the analytical and imaginative thoughts, and behavioural experiences refer to the actions (workout) being induced as the results of the brand stimuli. This four dimensions brand experience concept has been validated in a variety of product and service settings such as: tourism destinations (Beckman et al., 2013), consumer events (Zarantonello \& $\underline{\text { Schmitt, 2013) }}$, personal care products (Francisco-Maffezzolli et al., 2014), airlines (Lin, $\underline{2015}$ ) and coffeehouses (Choi et al., 2017).

\section{Brand Personality}

Brand personality is defined as human personality traits and characteristics (Japutra \& Molinillo, 2019). The bond between the brand and the consumer will be created from a brand that has a superior brand personality and is in accordance with the consumer's personality. To analyse the behaviour of a product or brand choice, you can use brand personality. There is a brand personality dimension introduced by Geuens et al., (2009) namely responsibility, activity, aggressiveness, simplicity, and emotionality.

\section{Brand Trust}

Research on trust has lasted for decades and many scholar have well defined trust in several different ways (Song et al., 2019). Trust has been conceptualized as a key variable in the exchange network between a firm and its customers because it encourages the long-term relationship. Trust is interpreted as a buyer's dream if the service provider can be trusted or prioritized when fulfilling the agreement (Rasidi \& Monika Tiarawati, 2021). Brand trust refers to the state where consumers are willing to rely on the brand because of its reliability and integrity to perform its stated function (Chaudhuri \& Holbrook, 2001).

Brand experiences result from stimulations and lead to pleasurable outcomes, and consumers want to repeat these experiences. Brand experience should affect not only past directed satisfaction judgments but also future directed consumer loyalty. Consumers should be more likely to buy a brand again and recommend it to others and less likely to buy an alternate brand (Mittal, 2001; Oliver, 1999). Previous research 
has stated that brand experience can positively affect consumer satisfaction and brand loyalty, as well as brand trust (Zarantonello \& Schmitt, 2010; Ha \& Perks, 2005). To summarize above mention, the hypotheses for this research are proposed as below:

$\mathrm{H}_{1}$ : Brand experience has a positive effect on brand loyalty

Brand personality is formed through consumer attitudes towards certain brands. In other words, the personality of a brand is in the minds or perceptions of consumers which are formed directly or indirectly through direct experience in using the product or through marketing efforts. Brand personality is formed through brand names, symbols or logos, advertisements, product attributes, spokespersons. According to Nguyen et al., (2011) in his research stated that brand loyalty is the main issue in marketing research. Brand loyalty as a deep commitment to repurchase the preferred product/service continuously in the future, thereby causing repurchase of the same brand or the same set of brands, even though it is influenced by the situation and marketing efforts (Oliver, 1999). Research from Brakus et al., (2009); Nysveen et al.,(2013); Lin, (2010) shows that brand personality has positive effect on brand loyalty. Thus, when they feel that the brand personality encourages them to express their selfconcept, these consumers will be loyal to the brand (Ekinci et al., 2013; Malär et al., 2011). To summarize above mention, the hypotheses for this research are proposed as below:

$\mathrm{H}_{2}$ : Brand personality has a positive effect on brand loyalty

Trust has an important effect on consumer commitment and brand loyalty (Gremler \& Brown, 1999). Brand trust refers to the state where consumers are willing to rely on the brand because of its reliability and integrity to perform its stated function (Chaudhuri \& Holbrook, 2001). With previous research which states that there is a positive influence between brand trust and brand loyalty (Sahin et al., 2011) and (Song et al., 2019). To summarize above mention, the hypotheses for this research are proposed as below:

H3: Brand trust has a positive effect on brand loyalty

\section{Method}

\section{Data Analysis}

This study conducted to determine the effect of brand experience, brand personality and brand trust on brand loyalty. This study is explanatory research. The method used in this study is a quantitative method using survey methods. Data collection techniques with this survey using a self-administered survey in which each questioner was filled by respondent directly (Cooper, D. R., \& Schindler, S, 2011). The total sample in this study was 150 respondents with the technique of taking with the 
method of purposive sampling. This study consists of 23 items statement and use 5 point Likert scale from strongly disagree (1) to strongly agree (5). Data analysis technique in this study using SPSS. Most of the respondents were female $(57,1 \%)$ and male $(42,9 \%)$. The majority of the respondents are $17-25$ years old (55\%). The majority of these respondents have income $1.500 .000-3.000 .000(32,7 \%)$ and frequency buying on lazada.co.id more than 5 times (32\%).

All constructs were measured using items adapted from previous studies on a five point scale disagree (1) to strongly agree (5). Brand experience was measured using nine items adopted from (Japutra \& Molinillo, 2019; Brakus et al., 2009). Brand personality was measured using six items adapted from (Japutra \& Molinillo, 2019). Brand trust was measured using five items adapted from (Song et al., 2019) and brand loyalty consist of three items was adopted from (Hwang et al., 2021).

Table 1. Definition and Operational Variable

\begin{tabular}{|c|c|c|}
\hline Variable & Items & Reference \\
\hline Brand Experience & 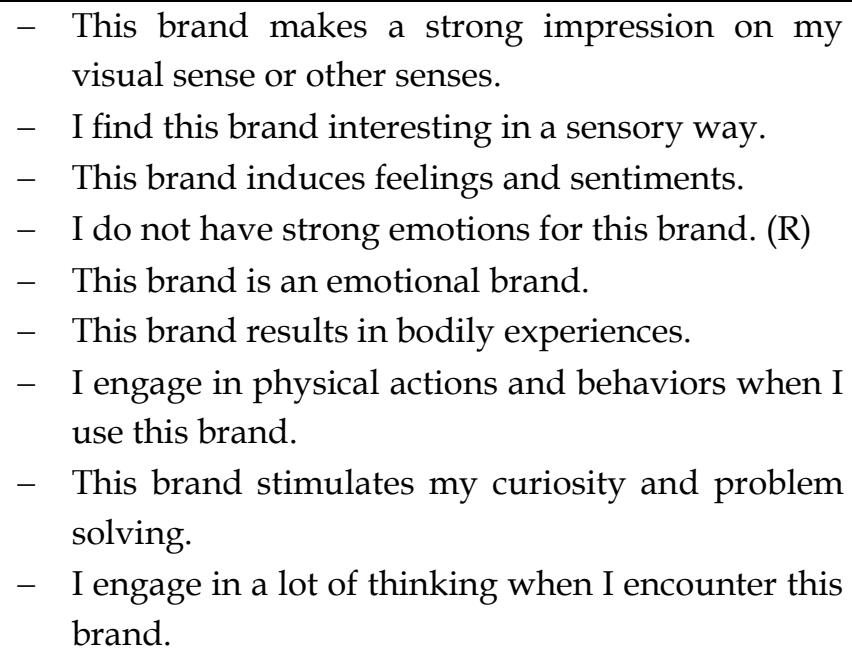 & $\begin{array}{l}\text { (Japutra \& } \\
\text { Molinillo, 2019) }\end{array}$ \\
\hline Brand personality & $\begin{array}{l}\text { - Down-to-earth } \\
- \text { Stable } \\
- \text { Responsible } \\
- \text { Dynamic } \\
- \text { Innovative } \\
- \text { Active }\end{array}$ & $\begin{array}{l}\text { (Japutra \& } \\
\underline{\text { Molinillo, 2019) }}\end{array}$ \\
\hline Brand Trust & $\begin{array}{l}\text { - I trust a brand } \\
\text { - I think a brand is a company that strives to keep its } \\
\text { promise to customers. } \\
\text { - I think a brand is stable for its customers. } \\
\text { - I would like a brand to continue to provide quality } \\
\text { services to its customers. } \\
\text { - A brand meets mv expectations }\end{array}$ & (Song et al., 2019) \\
\hline
\end{tabular}


Brand Loyalty

- I say positive things about a brand to others.

(Hwang et al.,

- I would like to use this brand more often.

$\underline{2021})$

- I would like to use this brand in the future.

Source: Data Processed (2021)

\section{Result and Discussion}

Table 2. The Result of Hypothesis Test

\begin{tabular}{lcccc}
\hline \multicolumn{1}{c}{$\begin{array}{c}\text { Independent } \\
\text { Variable }\end{array}$} & $\boldsymbol{\beta}$ & $\mathbf{t}$ & Sig. & Result \\
\hline Brand Experience => Brand & 1,036 & 19,584 & 0,000 & Supported \\
$\begin{array}{l}\text { Loyalty } \\
\text { Brand Personality => Brand }\end{array}$ & 0,693 & 8,342 & 0,000 & Supported \\
Loyalty & 0,718 & 9,935 & 0,000 & Supported \\
Brand Trust => Brand Loyalty &
\end{tabular}

Source: Data Processed (2021)

Hypothesis 1 states that brand experience has a positive effect on brand loyalty. Hypothesis 1 is using simple regression analysis. Based on coefficient and significant in table 2 , the results show that there is a positive and significant effect $(\beta=1,036 \mathrm{Sig}$ $=0,000)$, which means that brand experience has a positive and significant effect on brand loyalty, so it can be concluded that hypothesis 1 is supported. Hypothesis 2 states that brand personality has a positive effect on brand loyalty. Hypothesis 2 is using simple regression analysis. Based on coefficient and significant in table 2 , the results show that there is a positive and significant effect $(\beta=0,693$, Sig $=0,000)$, which means that brand personality has a positive and significant effect on brand loyalty, so it can be concluded that hypothesis 2 is supported. Hypothesis 3 states that brand trust has a positive effect on brand loyalty. Hypothesis is 3 using simple regression analysis. Based on coefficient and significant in table 2, the results show that there is a positive and significant effect $(\beta=0,718$, Sig $=0,000)$, which means that brand trust has a positive and significant effect on brand loyalty, so it can be concluded that hypothesis 3 is supported.

\section{Discussion}

Hypothesis 1 shows that brand experience has a positive effect on brand loyalty. This finding is in accordance with Şahin et al., (2011) that shows that brand trust has a positive effect on brand loyalty. It shows that the better the brand experience, it will increase brand loyalty. Based on these results indicate that hypothesis 1 in this study is supported. Hypothesis 2 shows that brand personality has a positive effect on brand loyalty. Based on these results indicate that hypothesis 2 in this study is supported. According to Mowen \& Minor, (2002), brand loyalty is a condition where consumers 
have a positive attitude of a brand and have a commitment. Several studies have shown that brand personality has the effect on brand loyalty Brakus et al., (2009); Lin, (2010); Nysveen et al., (2013); Japutra \& Molinillo, (2019); Sahin et al., (2011). It shows that brand personality has a positive effect on brand loyalty. It concluded that the better of brand personality, so it will increase of brand loyalty.

Hypothesis 2 shows that brand personality has a positive effect on brand loyalty. Based on these results indicate that hypothesis 3 in this study is supported. According to Mowen \& Minor, (2002), brand loyalty is a condition where consumers have a positive attitude of a brand and have a commitment. Several studies have shown that brand personality has the effect on brand loyalty Brakus et al., (2009); Lin, (2010); Nysveen et al., (2013); Japutra \& Molinillo, (2019); Sahin et al., (2011). It shows that brand personality has a positive effect on brand loyalty. It concluded that the better of brand personality, so it will increase of brand loyalty.

Hypothesis 3 shows that brand trust has a positive effect on brand loyalty. Brand trust is an expectation with confidence from the reliability of a brand in situations that involve risk. Brand trust refers to the state where consumers are willing to rely on the brand because of its reliability and integrity to perform its stated function (Chaudhuri \& Holbrook, 2001). Several studies have shown that brand trust has the effect on brand loyalty Sahin et al., (2011);Wongsansukcharoen, (2022); Song et al., (2019) and $\mathrm{Li}$ et al., (2020). This shows that the better of brand trust, it will increase brand loyalty. Based on these results indicate that hypothesis 3 in this study is supported.

\section{Conclusion}

Based on the results in this study show that all hypotheses supported. This study proves that brand experience has a positive effect on brand loyalty. Meanwhile, brand personality has a positive effect on brand loyalty and brand trust also has a positive effect on brand loyalty. It is expected to provide additional information and empirical evidence related to brand experience, brand trust, brand personality and brand loyalty. This research is expected to be input and suggestions for lazada.co.id site users in order to further increase purchases on the site with the experience that has been felt. Lazada.co.id can also improve their services to increase consumer loyalty. For future research is expected to use mediating variable or moderating variables such as satisfaction, or perceived value for relationship between brand experiences on brand loyalty.

\section{References}

Beckman, E., Kumar, A., \& Kim, Y. K. (2013). The Impact of Brand Experience on Downtown Success. Journal of Travel Research, 52(5), 646-658. https:/ / doi.org/10.1177/0047287513478502 
Brakus, J. J., Schmitt, B. H., \& Zarantonello, L. (2009). Brand Experience: What Is It? How Is It Measured? Does It Affect Loyalty? Journal of Marketing, 73(3), 52-68. https:/ / doi.org/10.1509/jmkg.73.3.52

Chaudhuri, A., \& Holbrook, M. B. (2001). The chain of effects from brand trust and brand affect to brand performance: The role of brand loyalty. Journal of Marketing, 65(2), 81-93. https:/ / doi.org/10.1509/jmkg.65.2.81.18255

Choi, Y. G., Ok, C. M., \& Hyun, S. S. (2017). Relationships between brand experiences, personality traits, prestige, relationship quality, and loyalty: An empirical analysis of coffeehouse brands. International Journal of Contemporary Hospitality Management, 29(4), 1185-1202. https:/ / doi.org/10.1108/IJCHM-112014-0601

Cooper, D. R., \& Schindler, S, P. (2011). Metode Riset Bisnis. Jakarta: Media.

Dennis, C., Joško Brakus, J., Gupta, S., \& Alamanos, E. (2014). The effect of digital signage on shoppers' behavior: The role of the evoked experience. Journal of Business Research, 67(11), 2250-2257.

https:/ / doi.org/10.1016/j.jbusres.2014.06.013

Ding, C. G., \& Tseng, T. H. (2015). On the relationships among brand experience, hedonic emotions, and brand equity. European Journal of Marketing, 49(7-8), 9941015. https:/ / doi.org/10.1108/EJM-04-2013-0200

Ekinci, Y., Sirakaya-Turk, E., \& Preciado, S. (2013). Symbolic consumption of tourism destination brands. Journal of Business Research, 66(6), 711-718. https:/ / doi.org/10.1016/j.jbusres.2011.09.008

Francisco-Maffezzolli, E. C., Semprebon, E., \& Muller Prado, P. H. (2014). Construing loyalty through brand experience: The mediating role of brand relationship quality. In Journal of Brand Management (Vol. 21, Issue 5, pp. 446-458). https:/ / doi.org/10.1057/bm.2014.16

Geuens, M., Weijters, B., \& De Wulf, K. (2009). A new measure of brand personality. International Journal of Research in Marketing, 26(2), 97-107. https:/ / doi.org/10.1016/j.ijresmar.2008.12.002

Gremler, D. D., \& Brown, S. W. (1999). The loyalty ripple effect. International Journal of Service Industry Management, 10(3), 271-293. https:/ / doi.org/10.1108/09564239910276872

Ha, H., \& Perks, H. (2005). Hong-Youl Ha. Journal of Consumer Behaviour Vol., 4(6), $438-452$.

Hwang, J., Choe, J. Y. (Jacey), Kim, H. M., \& Kim, J. J. (2021). Human baristas and robot baristas: How does brand experience affect brand satisfaction, brand attitude, brand attachment, and brand loyalty? International Journal of Hospitality Management, 99(March). https:// doi.org/10.1016/j.ijhm.2021.103050

Japutra, A., \& Molinillo, S. (2019). Responsible and active brand personality: On the relationships with brand experience and key relationship constructs. Journal of Business Research, 99(September 2017), 464-471.

https:/ / doi.org/10.1016/j.jbusres.2017.08.027 
Kotler, P., \& Keller, K. L. (2016). Marketing Management. In Marketing Management (15theditio ed.). Pearson Education.

Li, M. W., Teng, H. Y., \& Chen, C. Y. (2020). Unlocking the customer engagementbrand loyalty relationship in tourism social media: The roles of brand attachment and customer trust. Journal of Hospitality and Tourism Management, 44(July), 184-192. https://doi.org/10.1016/j.jhtm.2020.06.015

Lin. (2015). Innovative brand experience's influence on brand equity and brand satisfaction. Journal of Business Research, 68(11), 2254-2259. https://doi.org/10.1016/j.jbusres.2015.06.007

Lin, L. Y. (2010). The relationship of consumer personality trait, brand personality and brand loyalty: An empirical study of toys and video games buyers. Journal of Product $\mathcal{E}$ Brand Management, 19(1), 4-17. https:/ / doi.org/10.1108/10610421011018347

Malär, L., Krohmer, H., Hoyer, W. D., \& Nyffenegger, B. (2011). Emotional brand attachment and brand personality: The relative importance of the actual and the ideal self. In Journal of Marketing (Vol. 75, Issue 4, pp. 35-52). https://doi.org/10.1509/jmkg.75.4.35

Mittal, V. (2001). Intent, Satisfaction, Repurchase the Repurchase Behavior: Investigating of Customer Moderating Effect. Journal of Marketing Research, 38(1), 131-142.

Mowen, J. C., \& Minor, M. (2002). No Title. Penerbit Erlangga.

Nguyen, T. D., Barrett, N. J., \& Miller, K. E. (2011). Brand loyalty in emerging markets. Marketing Intelligence E Planning, 29(3), 222-232. https:/ / doi.org/10.1108/02634501111129211

Nysveen, H., Pedersen, P. E., \& Skard, S. (2013). Brand experiences in service organizations: Exploring the individual effects of brand experience dimensions. Journal of Brand Management, 20(5), 404-423. https:/ / doi.org/10.1057/bm.2012.31

Oliver, R. (1999). Whence Consumer Loyalty. Journal of Marketing, 63, 33-44.

Rasidi, W. A. R., \& Monika Tiarawati. (2021). The Effect of Convenience and Trust on Online Purchasing Decision (on Blibli Platform). Journal of Business and Management Review, 2(8), 531-543. https:/ / doi.org/10.47153/jbmr28.1862021

Şahin, A., Zehir, C., \& Kitapçi, H. (2011). The effects of brand experiences, trust and satisfaction on building brand loyalty; an empirical research on global brands. Procedia - Social and Behavioral Sciences, 24, 1288-1301.

https:/ / doi.org/10.1016/j.sbspro.2011.09.143

Song, H. J., Wang, J. H., \& Han, H. (2019). Effect of image, satisfaction, trust, love, and respect on loyalty formation for name-brand coffee shops. International Journal of Hospitality Management, 79(June 2018), 50-59. https:/ / doi.org/10.1016/j.ijhm.2018.12.011

Utami, W., Linda, W., \& Mulatsih, L. (2021). Analysis of Gender Difference on Online Shopping Lifestyle at Padang City. Journal of Business and Management Review, 2(8), 569-579. https:/ / doi.org/10.47153/jbmr28.2022021 
Wongsansukcharoen, J. (2022). Effect of community relationship management, relationship marketing orientation, customer engagement, and brand trust on brand loyalty: The case of a commercial bank in Thailand. Journal of Retailing and Consumer Services, 64(October 2021).

https://doi.org/10.1016/j.jretconser.2021.102826

Zarantonello, L., \& Schmitt, B. H. (2010). Using the brand experience scale to profile consumers and predict consumer behaviour. Journal of Brand Management, 17(7), 532-540. https:// doi.org/10.1057/ bm.2010.4

Zarantonello, L., \& Schmitt, B. H. (2013). The impact of event marketing on brand equity: The mediating roles of brand experience and brand attitude. International Journal of Advertising, 32(2), 255-280. https:/ / doi.org/10.2501/IJA-32-2-255-280 